\title{
Zooplankton assemblages in two reservoirs: one subjected to accentuated water level fluctuations, the other with more stable water levels
}

\author{
Ana Maria Geraldes · Maria-José Boavida
}

Received: 11 April 2006/ Accepted: 17 May 2006

(C) Springer Science+Business Media B.V. 2006

\begin{abstract}
The abundance, composition and dynamics of zooplankton were followed in two reservoirs of the River Douro catchment. The Serra Serrada Reservoir is subject to marked fluctuations in water levels. The highest values of total phosphorus, soluble reactive phosphorus, nitrate, water colour and chlorophyll $a$ were found during the minimum level phase. Rotifera was dominant except in late summer and autumn when the cladoceran Ceriodaphnia quadrangula or the copepod Tropocyclops prasinus replaced them as the dominant zooplankton. Among the rotifers the most common taxa were Keratella cochlearis, Conochilus sp. and Asplanchna priodonta. Maximum rotifer density was about 80,000 ind $\mathrm{m}^{-3}$ in 2000, 200,000 ind $\mathrm{m}^{-3}$ in 2001 and 100,000 ind $\mathrm{m}^{-3}$ in 2002. Among the crustacean zooplankton C. quadrangula achieved densities of up to 45,000 ind $\mathrm{m}^{-3}$ and $T$. prasinus, up to 80,000 ind $\mathrm{m}^{-3}$. Canonical correspondence analysis revealed
\end{abstract}

\section{A. M. Geraldes ( $\varangle)$}

CIMO, Instituto Politécnico de Bragança, Escola

Superior Agrária, Apartado 172, 5301-854 Bragança,

Portugal

e-mail: geraldes@ipb.pt

\section{M.-J. Boavida}

Centro de Biologia Ambiental, Departamento de

Biologia Animal, Faculdade de Ciências da

Universidade de Lisboa, Campo Grande C2, 1749-016

Lisboa, Portugal a strong contribution of the variation in the stored water volume, temperature, total phosphorus, chlorophyll, nitrates, and water transparency to the observed, significant association between zooplankton assemblage and environmental variables. In the Azibo Reservoir, fluctuations in water level are smaller. Only total phosphorus, cholorophyll and conductivity varied seasonally. Cladocera and Copepoda were dominant during the whole study period. The most abundant taxa were Ceriodaphnia pulchella, Daphnia longispina, Diaphanosoma brachyurum, Bosmina longirostris and Copidodiaptomus numidicus. Cladocera achieved densities of up to 25,000 ind $\mathrm{m}^{-3}$ and Copepoda up to 15,000 ind $\mathrm{m}^{-3}$. Rotifera in general reached densities of up to 6,000 ind $\mathrm{m}^{-3}$. On the basis of canonical correspondence analysis only temperature and conductivity were significantly associated with zooplankton assemblage.

Keywords Reservoirs · Water level fluctuations/ water stored volume $\cdot$ Zooplankton assemblage structure

\section{Introduction}

In regions where the rainfall is irregular and strongly seasonal and the water is used intensively by local populations, reservoirs are often subjected to marked fluctuations in water level. The 
composition, abundance and dynamics of the zooplankton populations are affected by several physical and chemical variables, which are largely influenced by the degree of these fluctuations (Wetzel 2001). An example of this is the increase in nutrient availability with greater fluctuations in water level observed by several authors (see Schmid-Araya and Zuñiga 1992; Naselli-Flores and Barone 1994; Watts 2000a, b); concomitantly, zooplankton showed a gradual shift from K-strategist towards r-strategist groups. Thus, an understanding of the mechanisms regulating these shifts may constitute an important source of information for the implementation of correct reservoir management practices. The present study was carried out on two reservoirs located in the Portuguese part of the River Douro catchment in the Trás-os-Montes region (NE Portugal). The Serra (S.) Serrada Reservoir was filled for the first time in 1995, and it has been found to be subjected to marked variations in the stored water volume. The Azibo Reservoir was created in 1982, and the observed variations in the volume of stored water are relatively much less.

The objectives of the present research were: (1) to determine zooplankton composition, abundance and dynamics during a 3-year cycle in both reservoirs; (2) to analyse whether the studied environmental variables could account for variations in zooplankton assemblages.

\section{Study sites}

The location, morphological and hydrological characteristics of both reservoirs are shown in Table 1. The climate in this region is continental, with warm, dry summers and long, cold winters. However, because of the influence of the Mediterranean climate in the Iberian Peninsula, precipitation and temperature vary greatly over the year and between years.

The S. Serrada Reservoir was built expressly as an urban water supply for 34,750 inhabitants (INE 2001) and to generate hydroelectric power. Consequently, the stored water volume suffers a marked reduction in the summer and late summer, inducing pronounced water level fluctuations (Fig. 1). The hydrological cycle of the
Table 1 Location and morphometric parameters of the Serra (S.) Serrada and Azibo reservoirs

\begin{tabular}{|c|c|c|}
\hline & S. Serrada & Azibo \\
\hline Location & $\begin{array}{l}\text { Latitude: } \\
41^{\circ} 57^{\prime}(\mathrm{N}) \\
\text { Longitude: } \\
6^{\circ} 46^{\prime}(\mathrm{W})\end{array}$ & $\begin{array}{l}\text { Latitude: } \\
41^{\circ} 32^{\prime}(\mathrm{N}) \\
\text { Longitude: } \\
6^{\circ} 53^{\prime}(\mathrm{W})\end{array}$ \\
\hline Altitude (m) & 1,300 & 500 \\
\hline Geology & $\begin{array}{l}\text { Granitic } \\
\text { bedrock }\end{array}$ & Schistic bedrock \\
\hline Watershed area $\left(\mathrm{km}^{2}\right)$ & 6.7 & 89.0 \\
\hline Reservoir area $\left(\mathrm{km}^{2}\right)$ & 0.25 & 4.10 \\
\hline Total capacity $\left(\mathrm{m}^{3}\right)$ & $1,680 \times 10^{3}$ & $54,470 \times 10^{3}$ \\
\hline Maximum depth (m) & 18 & 30 \\
\hline Mean depth (m) & 6.72 & 13.2 \\
\hline $\begin{array}{l}\text { Annual water } \\
\text { volume reduction (\%) }\end{array}$ & $81-95$ & $10.0-13.6$ \\
\hline Year of filling & 1995 & 1982 \\
\hline
\end{tabular}

reservoir is characterised by the following regime: (1) maximum level phase/maximum stored water volume, from January to the beginning of June; (2) emptying phase, from mid-June to the beginning of September; (3) minimum level phase/ minimum stored water volume, from mid-September to the beginning of the first autumn/winter rainfall. During the period of study (January 2000 to December 2002), thermal stratification was observed from June to August/beginning of September, with the disruption of stratification coincidental with the lowest water level. The water outlet is located at the deepest part of the reservoir. Although human influence on the reservoir seems to be negligible, grazing (sheep and goat) can be very intense in the catchment basin during the summer months. Consequently, fires over the surrounding land are often started by shepherds to obtain better grazing for their livestock. Fire and livestock excretions are considered to be the main potential allochthonous source of nitrogen and phosphorus.

The Azibo Reservoir was filled for the first time in 1982 and is used mainly for recreation. Although it is also used secondarily for water supply and irrigation, these factors do not significantly affect the water in the reservoir and, consequently, the seasonal reduction in the stored water volume is not very marked (Fig. 1). During the period of study, thermal stratification occurred from June to October. The direct influence of human activities on the impoundment is 
Fig. 1 Variations in stored water volume (SWV) in S. Serrada (A) and in Azibo (B) during the study period [source: INAG http:// www.snirh.inag.pt (2006)]
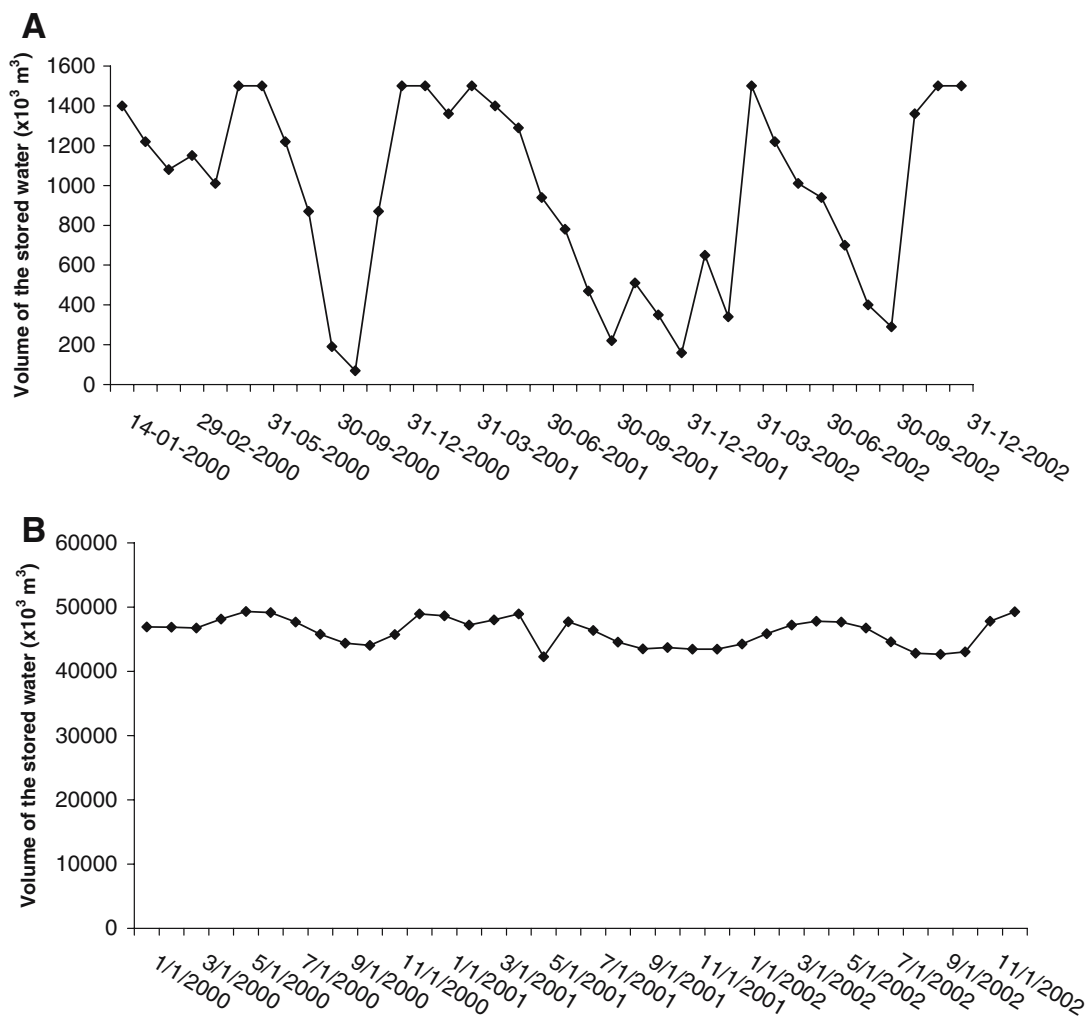

greatest during the summer when the reservoir and surroundings are used for recreational purposes, such as fishing, swimming, camping and boating. Other activities throughout the year on the surrounding land are farming and grazing (mainly sheep). Agriculture, grazing, sewage, angling and bathing can be considered to be the potential allochthonous sources of nitrogen and phosphorus in this reservoir.

Both reservoirs are considered to be mesoeutrophic, and their main source of water are small intermittent streams. For more detailed information on these reservoirs, see Geraldes and Boavida (2003).

\section{Materials and methods}

Zooplankton samples were collected at monthly intervals during the winter and at 2-week intervals during the summer, throughout three annual cycles, from January 2000 to December 2002. On each sampling date two vertical hauls (7-18 m long at S. Serrada and $20 \mathrm{~m}$ long at Azibo) were collected in the pelagic zone in both reservoirs using a Wisconsin-type net with a mesh size of $64 \mu \mathrm{m}$, which is fine enough to collect all of the rotifer species (A.M. Geraldes, personal observation). Sampling was always carried out at at the same sampling point. Animals were anaesthetised with carbonated water and preserved in sugarsaturated formaldehyde (4\% v/v final concentration). Depending on the density of animals in the sample, the zooplankton were counted in subsamples of $5,10,20 \mathrm{ml}$ or in the total sample. Because of the absence of molecular data which would have allowed us to establish their actual positioning in the "longispina" species complex, Daphnia species found in both reservoirs were identified on the basis of traditional morphological criteria.

Water samples for soluble reactive phosphorus (SRP) and total phosphorus (TP) determinations were taken from the upper $30-40 \mathrm{~cm}$ of the stratum, directly placed into acid-rinsed bottles and transported to the laboratory in a cold container. 
During stratification, samples were also obtained from the middle water column and from the bottom. SRP concentrations were estimated by the method of Murphy and Riley (1962), and TP was assessed after acid hydrolysis with persulfate for 60 min under high temperature and pressure (APHA 1989). Water samples for chlorophyll $a$ ( $\mathrm{CHL} a$ ) determination were obtained in the euphotic zone. Water from 500-1000 ml of sample, was filtered through a Whatman GF/A filter no more than $2 \mathrm{~h}$ after collection. Concentrations of CHL $a$ were determined spectrophotometrically after an overnight extraction in $90 \%$ acetone. Environmental variables such as water temperature, dissolved oxygen, conductivity, $\mathrm{pH}$, as well as nitrate $\left(\mathrm{N}-\mathrm{NO}_{3}\right)$, ammonium ion $\left(\mathrm{N}-\mathrm{NH}_{4}\right)$ and ammonia gas $\left(\mathrm{N}-\mathrm{NH}_{3}\right)$ were measured in situ with a 6820 YSI Multiparameter Water Quality Monitor (Yellow Springs, Ohio). Water transparency was measured with a $20-\mathrm{cm}$ black and white Secchi disk.

A Kruskal-Wallis test (Sokal and Rohlf 1981) was performed for each environmental variable to determine whether mean values, obtained at the maximum water level phase, at the emptying phase and at the minimum water level phase, were significantly different in S. Serrada. In Azibo, the same procedure was used to test whether mean values obtained at late October/ early June (maximum level) and at late June/early October (minimum level) were significantly different. This test was performed using SYSTAT 8.0 (SSPS, Chicago, Ill.). The statistical association between zooplankton assemblage structure and environmental variables was quantified with the canonical correspondence analysis (CCA) using the CANOCO 4 computer programme. In this analysis, taxa were included only if they reached a relative abundance larger than 1\%. Absolute zooplankton counts (numerical abundances) were transformed to $\log (x+1)$, and rare species were down-weighted. Environmental variables included in CCA were conductivity, temperature, $\mathrm{pH}$, dissolved oxygen, SRP, TP, N-NO $3, \mathrm{~N}-\mathrm{NH}_{4}$, CHL $a$, Secchi depth and the stored water volume variation (SWV). In CCA the automatic forward selection procedure by Monte Carlo permutation tests (9999 permutations) was used to remove the redundant environmental variables, thereby allowing the selection of those contributing most to the explanation of the whole data set (Ter Braak 1995).

\section{Results}

\section{S. Serrada Reservoir}

Mean TP, $\mathrm{N}-\mathrm{NO}_{3}$, water colour, conductivity and CHL $a$ concentrations were the highest during the minimum water level phase; water transparency was the lowest during the same period. SRP mean concentrations were also slightly higher during this period than during the other months of the year. TP, CHL $a$ and conductivity decreased during the maximum water level phase. Mean $\mathrm{N}^{-\mathrm{NO}_{3}}$ decreased during the emptying phase (Table 2). $\mathrm{N}^{-\mathrm{NH}_{3}}$ concentrations were always below detection limits. During the period of highest rainfall (autumn and winter), this reservoir reached the maximum level phase in 1 or 2 weeks. Therefore, at the beginning of the maximum level phase $\mathrm{TP}, \mathrm{N}-\mathrm{NO}_{3}$, water colour and CHL $a$ values were high, gradually decreasing thereafter. The zooplankton assemblage was characteristically dominated by Rotifera, except in the summer and autumn when Cladocera [mainly Ceriodaphnia quadrangula (Müller)] and Copepoda [mainly Tropocyclops prasinus (Fisher)] became dominant (Fig. 2A) Therefore, the most abundant rotifer species were Keratella cochlearis (Gosse), Conochilus sp., Polyarthra sp. and Synchaeta sp. (Table 3). During the period of study $K$. cochlearis densities ranged between 0 and 260,536 ind $\mathrm{m}^{-3}$; Conochilus sp. varied between 0 and 54,137 ind $\mathrm{m}^{-3}$; Polyarthra sp. ranged from 0 to 36,606 ind $\mathrm{m}^{-3}$; Synchaeta $\mathrm{sp}$. ranged from 0 to 16,326 ind $\mathrm{m}^{-3}$. Ceriodaphnia and $T$. prasinus maximum values were 40,107 and 71,928 ind $\mathrm{m}^{-3}$, respectively (Fig. 3). The forward variable selection approach to $\mathrm{CCA}$ revealed a strong contribution of the SWV $(p=0.001)$, temperature (Temp.) $(p=0.001), \mathrm{TP}$ $(p=0.001)$, Chl $a(p=0.003), \mathrm{N}^{-N}{ }_{3}(p=0.018)$ and water transparency $(p=0.024)$ to the observed significant association between zooplankton assemblage and environmental variables (Monte-Carlo test; $p=0.0001$ ). The ordination 
Table 2 Mean \pm standard deviation (SD) values of the environmental variables and minimum-maximum range for $\mathrm{pH}$ obtained for the maximum level phase (1), emptying phase (2) and minimum level phase (3) in S. Serrada

\begin{tabular}{|c|c|c|c|c|}
\hline Variables $^{\mathrm{a}}$ & 1 & 2 & 3 & $p$ \\
\hline Water transparency (m) (Secchi) & $2.9 \pm 0.9$ & $2.9 \pm 1.0$ & $1.7 \pm 0.4$ & $* *$ \\
\hline Water temperature $\left({ }^{\circ} \mathrm{C}\right)$ (Temp.) & $9.3 \pm 5.5$ & $19.4 \pm 1.3$ & $10.2 \pm 4.1$ & $* *$ \\
\hline Dissolved oxygen $\left(\mathrm{mg} \mathrm{l}^{-1}\right)(\mathrm{DO})$ & $8.6 \pm 1.6$ & $8.4 \pm 0.9$ & $8.6 \pm 1.5$ & NS \\
\hline Conductivity $\left(\mu \mathrm{s} \mathrm{cm}^{-1}\right)$ (Cond.) & $6.0 \pm 1.5$ & $8.3 \pm 0.8$ & $8.1 \pm 1.5$ & $* *$ \\
\hline $\mathrm{pH}(\mathrm{PH})$ & $6.9-7.4$ & $5.4-8.1$ & $7.0-8.5$ & NS \\
\hline $\mathrm{N}-\mathrm{NO}_{3}\left(\mathrm{mg} \mathrm{l}^{-1}\right)\left(\mathrm{NO}_{3}\right)$ & $5.8 \pm 8.7$ & $0.9 \pm 0.8$ & $13.3 \pm 15.2$ & $* *$ \\
\hline $\mathrm{N}-\mathrm{NH}_{4}\left(\mathrm{mg} \mathrm{l}^{-1}\right)\left(\mathrm{NH}_{4}\right)$ & $0.2 \pm 0.5$ & $0.1 \pm 0.2$ & $0.4 \pm 0.8$ & NS \\
\hline $\mathrm{TP}\left(\mu \mathrm{g} \mathrm{l}^{-1}\right)(\mathrm{TP})$ & $59.9 \pm 25.3$ & $70.1 \pm 19.2$ & $82.0 \pm 11.4$ & $* *$ \\
\hline $\operatorname{SRP}\left(\mu \mathrm{g} \mathrm{l}^{-1}\right)(\mathrm{SRP})$ & $8.7 \pm 7.5$ & $6.6 \pm 4.7$ & $9.5 \pm 7.2$ & NS \\
\hline Chlorophyll $a\left(\mu \mathrm{g} \mathrm{l}^{-1}\right)(\mathrm{CHL})$ & $1.7 \pm 1.3$ & $1.9 \pm 1.6$ & $8.0 \pm 4.7$ & $* *$ \\
\hline
\end{tabular}

Kruskal-Wallis test: $* p<0.05, * * p<0.01$; NS, not significant

${ }^{a}$ Abbreviations used in the CCA are indicated in parenthesis
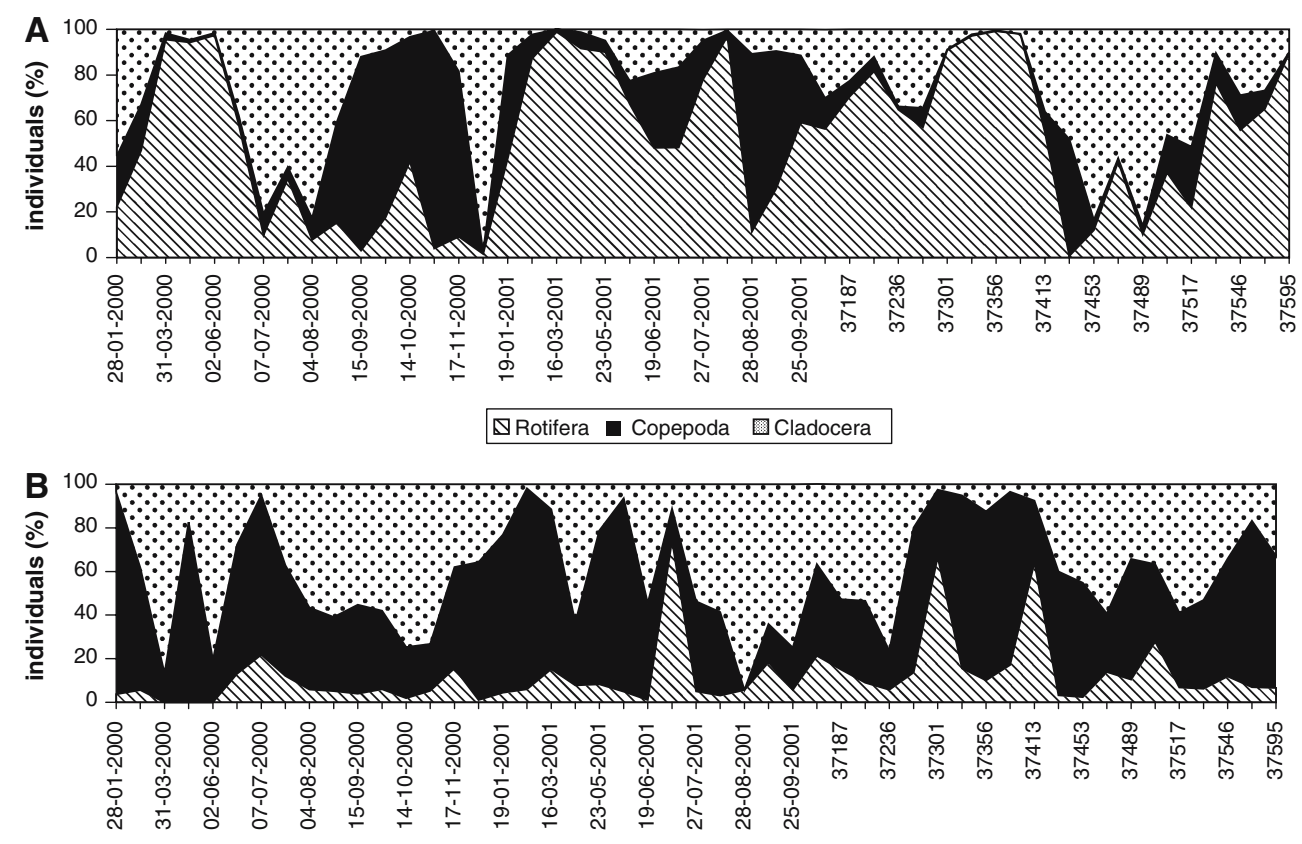

$\triangle$ Rotifera $\square$ Copepoda $\quad$ Cladocera

Fig. 2 Relative abundance (\%) of Rotifera, Copepoda and Cladocera in the S. Serrada (A) and Azibo (B) reservoirs

space defined by the first two CCA axes (Fig. 5A) accounted for $71.4 \%$ of species environment relations and represented $29.2 \%$ of the variation in species data. Conochilus, Polyarthra and Asplanchna were associated with lower temperature and TP values, higher reservoir water stored volume (maximum level phase) and water transparency. Synchaeta, Keratella, T. prasinus and Ceriodaphnia abundances were related to the increase in system instability and to the highest nutrient, Chl $a$ and temperature values (emptying and minimum level phases).

\section{Azibo Reservoir}

In Azibo only mean TP, water transparency, $\mathrm{pH}$ and CHL $a$ were significantly different between the maximum and minimum levels (Table 4). $\mathrm{N}-\mathrm{NH}_{3}$ concentrations were always below detection limits. Zooplankton assemblage was dominated 
Table 3 Mean \pm SD values of the environmental variables and minimum-maximum range for $\mathrm{pH}$ obtained for late October/early June period (1), late June/early October (2) in Azibo

\begin{tabular}{|c|c|c|c|}
\hline Variables $^{\mathrm{a}}$ & 1 & 2 & $p$ \\
\hline Water transparency $(\mathrm{m})$ (Secchi) & $3.5 \pm 1.3$ & $5.0 \pm 1.4$ & $* *$ \\
\hline Water temperature $\left({ }^{\circ} \mathrm{C}\right)$ (Temp.) & $12.4 \pm 4.4$ & $21.5 \pm 2.3$ & $* *$ \\
\hline Dissolved oxygen $\left(\mathrm{mg} \mathrm{l}^{-1}\right)$ (DO) & $9.0 \pm 1.4$ & $8.6 \pm 0.8$ & NS \\
\hline Conductivity $\left(\mu \mathrm{S} \mathrm{cm}^{-1}\right)$ (Cond.) & $54.7 \pm 7.9$ & $70.8 \pm 3.2$ & $* *$ \\
\hline $\mathrm{pH}(\mathrm{PH})$ & $5.4-8.2$ & $7.1-8.4$ & NS \\
\hline $\mathrm{N}-\mathrm{NO}_{3}\left(\mathrm{mg} \mathrm{l}^{-1}\right)\left(\mathrm{NO}_{3}\right)$ & $5.7 \pm 6.1$ & $3.2 \pm 4.1$ & NS \\
\hline $\mathrm{N}-\mathrm{NH}_{4}\left(\mathrm{mg} \mathrm{l}^{-1}\right)\left(\mathrm{NH}_{4}\right)$ & $0.5 \pm 1.1$ & $0.5 \pm 1.2$ & NS \\
\hline $\mathrm{TP}\left(\mu \mathrm{g} \mathrm{l}^{-1}\right)(\mathrm{TP})$ & $56.6 \pm 15.2$ & $68.9 \pm 13.6$ & $* *$ \\
\hline $\operatorname{SRP}\left(\mu \mathrm{g} \mathrm{l}^{-1}\right)(\mathrm{SRP})$ & $6.1 \pm 5.3$ & $5.9 \pm 4.4$ & NS \\
\hline Chlorophyll $a\left(\mu \mathrm{g} \mathrm{l}^{-1}\right)(\mathrm{CHL})$ & $1.8 \pm 1.4$ & $1.1 \pm 1.3$ & $*$ \\
\hline
\end{tabular}

Kruskal-Wallis test: ${ }^{*} p<0.05, * * p<0.01$; NS, not significant

${ }^{a}$ Abbreviations used in the CCA are indicated in parenthesis

by Cladocera or Copepoda, except in the samplings from 13 July 2001, 14 February 2002 and 6 June 2002 when the rotifer Polyarthra sp. was dominant (Fig. 2B). The most abundant Cladoceran species reported in Azibo were: Daphnia longispina Müller, Ceriodaphnia pulchella Sars, Bosmina longirostris Müllerand Diaphanosoma brachyurum Liéven. Two species of Copepoda were found: The calanoid Copidodiaptomus $n u$ midicus Gurney, and the cyclopoid Acanthocyclops robustus Sars, the former dominating over the latter. Rotifera was dominated by Polyarthra sp., Asplanchna priodonta, Keratella cochlearis and Conochilus sp. (Table 3). Daphnia densities ranged between 0 and 9549 ind $\mathrm{m}^{-3}$; Ceriodaphnia varied between 0 and 24,605 ind $\mathrm{m}^{-3}$ in 2000; Bosmina ranged from 0 to 1401 ind $\mathrm{m}^{-3}$. Diaphanosoma was present only in the summer months and during this season its density varied between 64 and 1783 ind $\mathrm{m}^{-3}$. C. numidicus densities ranged between 40 and 15,024 ind $\mathrm{m}^{-3}$, whereas $A$. robustus densities varied from 0 to 860 ind $\mathrm{m}^{-3}$ (Fig. 4). The forward variable selection approach to CCA only revealed a strong contribution of temperature $(p=0.0001)$ and conductivity ( $p=0.0002)$ to the observed significant association between zooplankton assemblage and environmental variables (Monte-Carlo test; $p=0.006)$. The ordination space defined by the first two CCA axis (Fig. 5B) accounted for $100 \%$ of species environment relations and represented $32.1 \%$ of the variation in species data. Bosmina, Ceriodaphnia and Diaphanosoma were associated with high temperatures and conductivity, whereas Daphnia, C. numidicus, A. robustus, Asplanchna, Polyarthra, Keratella and nauplii showed the reverse trend.

\section{Discussion}

\section{S. Serrada Reservoir}

In comparison to other reservoirs of similar dimension and located in similar geological and climatic regions (see Boavida 2000; Negro et al. 2000) S. Serrada can be considered to be a highly disturbed system. In fact, internal disturbance caused by fluctuations in the water level is intense. The increase in TP, N-NO $\mathrm{N}_{3}$ and $\mathrm{CHL} a$ concentrations during the emptying and minimum level phases could have been the result of the increment in suspended particulate material in the water column. This increment might have resulted from water turbulence generated during the emptying phase plus the disruption of stratification at the end of this phase. The existence of large amounts of suspended particulate material in the water column during the emptying phase (A.M. Geraldes, personal observation) might have been a consequence of the existing vegetation not having been removed before the filling of the reservoir area (see Kimmel et al. 1988; Robarts et al. 1992). Nutrients decreased during the maximum level phase. As this phase is a period of water level stability, the sedimentation 

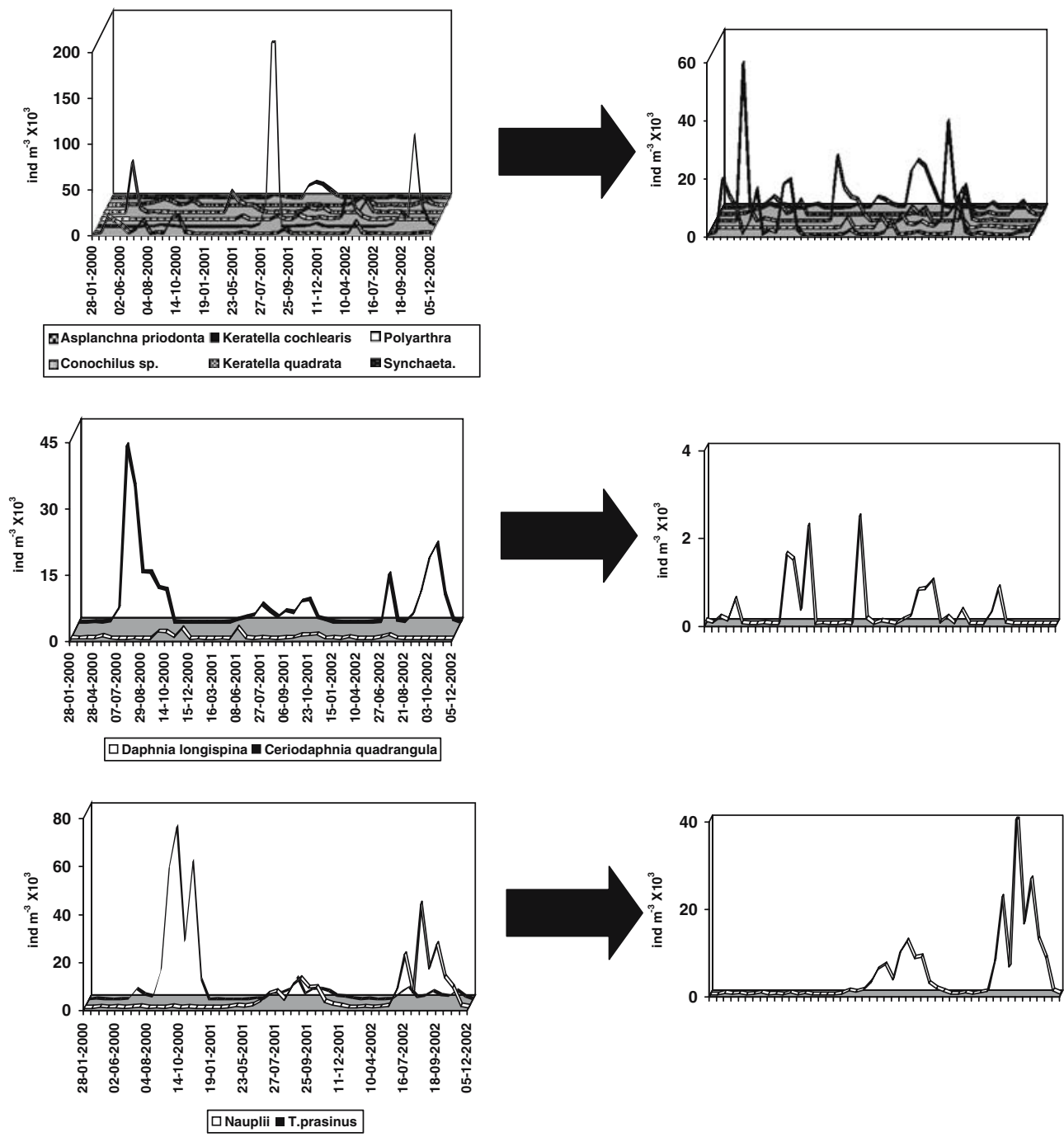

Fig. 3 Annual variation of zooplankton abundance and composition in the S. Serrada Reservoir. Graphics on the right are without the taxon with the largest density peaks

of particulate material could have been favoured (Boström et al. 1988; Wetzel 2001). Similar patterns of variations in the amounts of nutrient and suspended particulate material were observed by Naselli-Flores and Barone (1994) and NaselliFlores (1999) in Sicilian reservoirs subjected to severe reductions in water volume. Another consequence of the disturbance caused by extreme water volume reduction is the exposure of littoral sediments to cycles of drying and wetting, which might have implications on nutrient cycling, namely on phosphorus availability. This assumption is supported by the results obtained by Watts $(2000 a, b)$ in reservoirs where water level fluctuations are marked and where refilling took place over a short period of time. According to this author, littoral sediments that are periodically exposed, thereby experiencing cycles of drying and wetting, have a lower capacity to adsorb nutrients than those that always remain submerged. Preliminary experiments based upon the experimental design developed by the Watts (2000a, b) and performed in S. Serrada revealed a similar pattern (A. M. Geraldes unpublished).

Specialists in small particle feeding, whose food preferences are mostly comprised of detritus-bacteria and small phytoplankton, always dominated the zooplankton assemblage in this 
Table 4 Mean densities (ind $\mathrm{m}^{-3}$ ) and percentage of occurrence of the zooplankton taxa found in both reservoirs

\begin{tabular}{|c|c|c|c|}
\hline \multicolumn{2}{|l|}{ S. Serrada } & \multicolumn{2}{|l|}{ Azibo } \\
\hline Zooplankton $^{\mathrm{a}}$ & $\begin{array}{l}\text { Mean } \\
\text { densities }\end{array}$ & Zooplankton $^{\mathrm{a}}$ & $\begin{array}{l}\text { Mean } \\
\text { densities }^{b}\end{array}$ \\
\hline \multicolumn{2}{|l|}{ Rotifera } & \multicolumn{2}{|l|}{ Rotifera } \\
\hline $\begin{array}{l}\text { Keratella cochlearis } \\
\text { (Gosse) (Kera.) }\end{array}$ & $9380.5(27.4)$ & Polyarthra sp. (Poly.) & $1181.2(8.7)$ \\
\hline $\begin{array}{l}\text { Asplanchna priodonta } \\
\text { Gosse (Aspl.) }\end{array}$ & $2689.2(7.9)$ & Asplanchna priodonta Gosse (Aspl.) & $513.9(3.8)$ \\
\hline Conochilus sp. Ehrb. (Cono.) & $2857.9(8.4)$ & Keratella cochlearis (Gosse) (Kera.) & $226.4(1.7)$ \\
\hline Polyarthra sp. Ehrb. (Poly.) & $1559.0(4.6)$ & Synchaeta sp. Ehrb. & $96.5(0.7)$ \\
\hline Synchaeta sp. Ehrb. (Sync.) & $1486.5(4.3)$ & Gastropus sp. Imhof & $81.4(0.6)$ \\
\hline Keratella quadrata (Müller) (Kqua.) & $998.0(2.9)$ & Collotheca mutabilis (Hudson) & $18.7(0.1)$ \\
\hline Hexarthra sp. Schmarda & $144.7(0.4)$ & Conochilus sp. Ehrb. & $7.1(0.1)$ \\
\hline Ploesoma sp. Herrick & $35.7(0.1)$ & Hexarthra sp. & $2.4(0.02)$ \\
\hline Gastropus sp. Imhof & $31.2(0.1)$ & Keratella quadrata (Müller) & $2.0(0.01)$ \\
\hline Trichocerca sp. Lamark & $1.6(0.004)$ & Pompholix sulcata (Hudson) & $1.7(0.01)$ \\
\hline Euchelanis sp. Ehrb. & $1.3(0.003)$ & Filinia sp. Bory de St. Vincent & $1.0(0.01)$ \\
\hline Collotheca sp. Harring & $1.1(0.003)$ & & \\
\hline \multicolumn{2}{|l|}{ Cladocera } & \multicolumn{2}{|l|}{ Cladocera } \\
\hline $\begin{array}{l}\text { Ceriodaphnia quadrangula } \\
\text { (Müller) (Ceri.) }\end{array}$ & $4108.7(12.0)$ & Ceriodaphnia pulchella Sars (Ceri.) & $4078.7(30.0)$ \\
\hline Daphnia longispina & $279.8(0.9)$ & Daphnia longispina (Müller) (Daph.) & $1093.5(8.1)$ \\
\hline Chydorus sphaericus Müller & $29.7(0.1)$ & $\begin{array}{l}\text { Diaphanosoma brachyurum Liéven } \\
\text { (Diap.) }\end{array}$ & $355.3(2.6)$ \\
\hline Alona sp. & $28.2(0.1)$ & Bosmina longirostris Müller (Bosm.) & $172.8(1.3)$ \\
\hline Alona costata Sars & & Daphnia pulex Leydig & $30.6(0.2)$ \\
\hline Alona rectangula Sars & & Alona sp. & $9.9(0.1)$ \\
\hline Alona quadrangularis Müller & & Alona costata & \\
\hline Bosmina longirostris Müller & $14.7(0.04)$ & Alona rectangula & \\
\hline \multirow[t]{2}{*}{ Simocephalus sp. Schoedler } & $2.6(0.01)$ & Alona quadrangularis & \\
\hline & & Chydorus sphaericus & $3.2(0.02)$ \\
\hline & \multicolumn{2}{|l|}{ Copepoda } \\
\hline Tropocyclops prasinus (Fisher) (Tpra.) & $6094.4(17.8)$ & $\begin{array}{l}\text { Copidodiaptomus numidicus Gurney } \\
\text { (Copi.) }\end{array}$ & $4457.3(32.8)$ \\
\hline Nauplii (Naup.) & $4414.3(12.9)$ & Nauplii (Naup) & $1072.2(7.9)$ \\
\hline Eucyclops serrulatus (Fisher) & $25.2(0.1)$ & $\begin{array}{l}\text { Acanthocyclops robustus Sars } \\
\text { (Acan.) }\end{array}$ & $167.0(1.2)$ \\
\hline Macrocyclops albidus (Jurine) & $10.8(0.03)$ & & \\
\hline
\end{tabular}

${ }^{\mathrm{a}}$ Abbreviations used in CCA are indicated in parenthesis

${ }^{\mathrm{b}}$ Values are presented as mean densities (ind $\mathrm{m}^{-3}$ ); the percentage of occurrence is given in parenthesis

reservoir. Most zooplanktons, Ceriodaphnia and $T$. prasinus included, can only consume particles smaller than $20 \mu \mathrm{m}$ (Lampert and Sommer 1997). These assemblage patterns are typical of reservoirs subjected to periodic water level variations (see Armengol et al. 1988; Schmid-Araya and Zuñiga 1992; Błedzki and Ellinson 2000). According to those authors, the above-mentioned species have adaptive advantages in disturbed environments not only on account of their feeding behaviour, but also because they are r-strategists, thereby having shorter generation times and a greater tolerance to large amounts of organic matter in the water. An exception was Conochilus which, according to Sladeček (1983), is typical of environments poor in organic matter. This taxon is subsequently replaced by taxa typical of more eutrophic environments. CCA revealed that zooplankton assemblage patterns might be significantly associated with three kinds of environmental variables: (1) stored water volume; (2) those whose changes seemed to be directly 

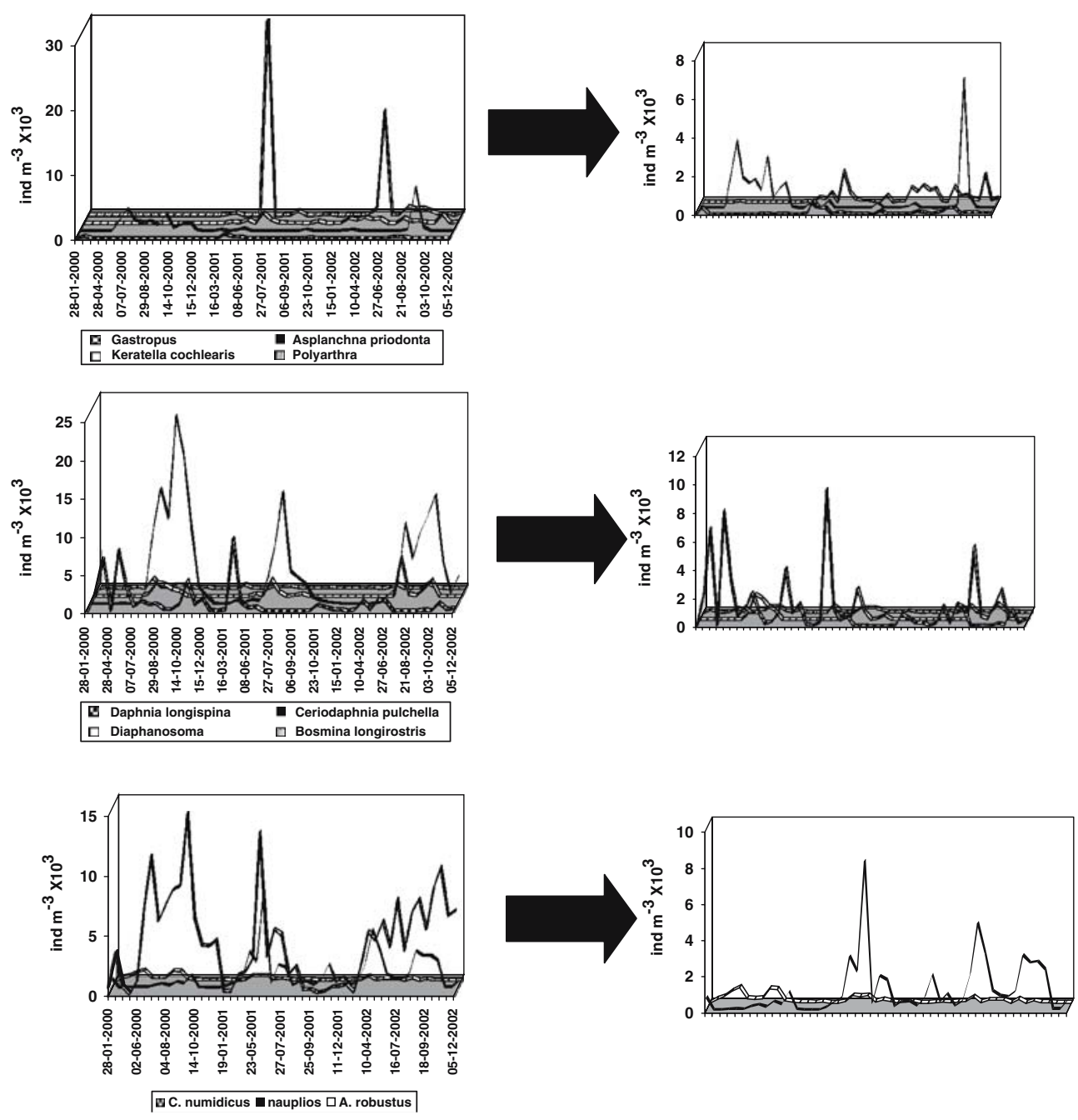

Fig. 4 Annual variation of zooplankton abundance and composition in the Azibo Reservoir. Graphics on the right are without the taxon with the largest density peaks

influenced by water level fluctuations (e.g. nutrient concentrations); (3) those also varying seasonally, although independently of water level fluctuations (e.g. temperature). However, zooplankton seasonal succession could have been related not only to changes in environmental variables, whether caused by water level variation or not, but also to changes in biotic parameters (e.g. in phytoplankton assemblage). In fact, according to Geraldes and Boavida (2005) Monoraphidium, Cyclotella and Tabellaria were dominant during the maximum water level phase, whereas Peridinium, Cosmarium, Anabaena, Staurastrum, Crucigenia and Scenedesmus were more abundant during the minimum level phase.
Therefore, since a wide range of physical, chemical and biological complex interactions are likely to influence zooplankton assemblages, it is necessary to be cautious when relating the changes observed in the present study to variations in the water level/stored water volume.

In the absence of chronological data, it is difficult to relate reservoir age to zooplankton assemblage patterns. However, it is plausible to suggest that zooplankton assemblage structure could also be a consequence of reservoir age (e.g. Pinel-Alloul and Méthot 1984; Robarts et al. 1992). As this is a recently formed reservoir, a climax community had most likely not yet established at the time of this study. 

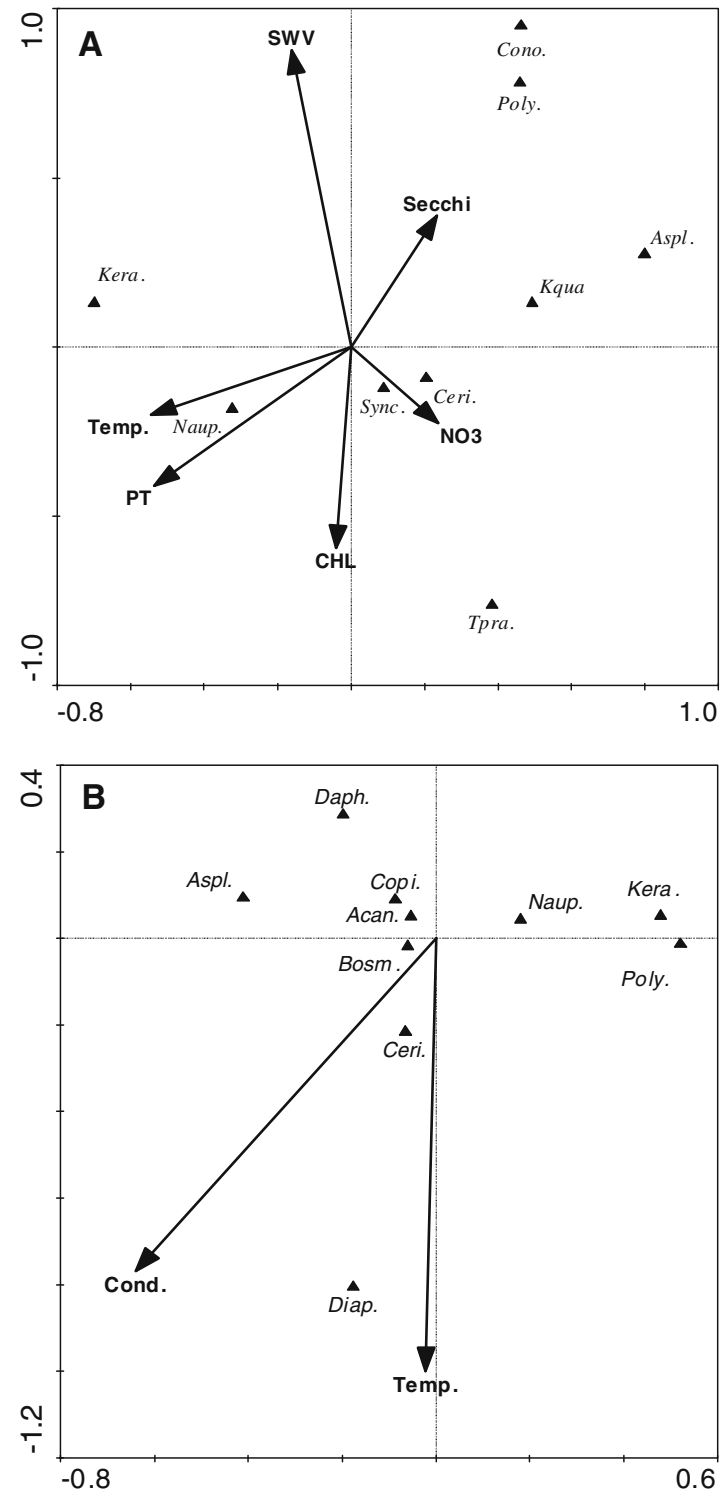

Fig. 5 Results of the CCA: S. Serrada (A), Azibo (B). Species abbreviations are shown in Table 4

\section{Azibo Reservoir}

In Azibo internal disturbance caused by water level fluctuations seems to be minimal. Consequently, changes in environmental variables (nutrient concentrations and water transparency, among others) were not very accentuated. The increase in mean TP concentrations during the late spring/summer months were probably caused by: (1) particle transportation by wind from reservoir surroundings (see Cole et al. 1990); (2) the senescence of emergent macrophytes that colonise some shallow areas of the reservoir (see James and Barko 1991). Zooplankton assemblage patterns seemed to be significantly associated only with conductivity and temperature. Geraldes and Boavida (2004a, b) observed that seasonal succession in zooplankton assemblage was strongly influenced by temperature. In support of their results, we found that during the winter and early spring months Daphnia was dominant and Ceriodaphnia was virtually absent. After this period, Daphnia's population decreased to undetectable levels, while concurrentlyCeriodaphnia's population increased to its maximum density, becoming dominant from July to September. During this period Daphnia was not detected in samples, indicating that it was present at extremely low densities. Lynch (1978) also observed the replacement of Daphnia by Ceriodaphnia during the summer and attributed this phenomenon to the better efficiency of Ceriodaphnia to feed at temperatures above $20^{\circ} \mathrm{C}$. Diaphanosoma was only detected during the summer, and this species is typical of warm water, being largely confined to mid- or late-summer in seasonal temperate lakes (Hart 2000). However, zooplankton assemblage features can be not only a consequence of low disturbance and temperature but also a consequence of fish assemblage shift and/or reservoir age. According to several authors, large zooplankton are especially susceptible to fish predation (Beklioglu and Moss 1996; Caramujo et al. 1997; Lampert and Sommer 1997). Siegfried and Kopache (1984) observed that the increased predation by $0+$ fish and by planktivorous fish at the beginning of summer led to a decline in the Daphnia population. Up to the 1980s cyprinid fish were dominant in Azibo (Formigo 1990). Consequently, they could have had some impact on the cladoceran and copepod assemblages. Vasconcelos (1990a, b) reported that at this time the zooplankton assemblage was dominated by rotifers, which may be evidence of the existence of a considerable predation pressure by fish. Cyprinids are not strictly planktivorous, but they can have some impact on Daphnia and on other large-bodied zooplankton in some lakes and reservoirs (Winfield and Townsend 1992). However, the introduction of pike (Esox lucius) 
in the 1990s led to an accentuated decrease in the resident cyprinid fish densities. Therefore, the impact of cyprinid predation on cladoceran and copepod assemblages might have been minimised. On the other hand, pike alevins feed on Daphnia and copepods during the first few weeks of life, after absorbing the yolk sac and before being able to feed on macroinvertebrates and, subsequently, fish (Hunt and Carbine 1951). In this way, very young pike might have a very small temporary impact on cladoceran and copepod assemblages. However, it is difficult to assess if this shift in zooplankton assemblage was induced by changes in the fish assemblage or caused by other factors, such as the increasing age of the reservoir and the "stabilisation" of environmental conditions.

\section{Conclusions}

The present results suggest the following conclusion: even though conductivity, water temperature, nutrients and variations in the stored water volume (in S. Serrada) can explain some of the variability, abundance and composition of zooplankton, it is plausible to hypothesise that other factors, such as the age of the reservoirs and biotic interactions, could also play an important role in the structuring of those assemblages. However, the data obtained in this study do not provide an objective answer to these hypotheses. Therefore, complementary field work and experimental research should be carried out. There is a lack of long-term data on environmental variation patterns and their influence on biotic community dynamics. Furthermore, it is important to understand to what extent shifts in reservoir dynamics (mainly in the biotic components) are induced by water fluctuations and/or by seasonal factors acting independently of water fluctuations. Such data are fundamental to develop predictive water quality models adapted to this particular area, rendering possible the development of correct management practices with a multipurpose use perspective for the reservoir and its catchment. In addition, this data will add to the understanding of the limnology of reservoir ecosystems influenced by the Mediterranean climate.
Acknowledgements This study was financed by Fundação para a Ciência e a Tecnologia, Portugal (PRAXIS XXI/C/BIA/11012/98). AMG was awarded a 4/5.3/PRODEP/2000 doctoral fellowship. M. J. Caramujo kindly provided copepod identification. The assistance of A. Ribeiro, A. Teixeira and N. Marcos in the field is appreciated. Pertinent comments and suggestions by an anonymous referee are appreciated.

\section{References}

APHA (1989) Standard methods for the examination of water and wastewater. American Public Health Association, Washington D.C.

Armengol J, Sabater F, Riera JL et al. (1988) Longitudinal changes in the zooplankton communities along a series of reservoirs in the Guadiana River (W Spain). Verh Int Verein Limnol 23:1006-1010

Błedzki LA, Ellinson AM (2000) Effects of water retention time on zooplankton of shallow rheolimnic reservoirs. Verh Int Verein Limnol 27:2865-2869

Beklioglu M, Moss B (1996) Mesocosm experiments on the interaction of sediment influence, fish predation and aquatic plants with the structure of phytoplankton and zooplankton communities. Freshw Biol 36:315325

Boavida MJ (2000) The lakes of Serra da Estrela (Portugal). In: Martínez IG, Velasco MT (eds) Conservación de los lagos y humedales de alta montaña de la Península Ibérica. Universidad Autónoma de Madrid, Madrid, pp 79-86

Boström B, Persson G, Broberg B (1988) Bioavailability of different phosphorus forms in freshwater systems. Hydrobiologia 170:21-34

Caramujo MJ, Crispim MC, Boavida MJ (1997) Assessment of the importance of fish predation versus copepod predation on life history traits of Daphnia hyalina. Hydrobiologia 360:243-252

Cole JJ, Caraco NF, Likens GE (1990) Short-range atmospheric transport: a significant source of phosphorus to an oligotrophic lake. Limnol Oceanogr 35:1230-1237

Formigo N (1990) Ictiofauna. In IZAN (ed) Caracterização ecológica da albufeira do Azibo, com vista à determinação das suas potencialidades no domínio dos recursos vivos, Acções Preparatórias do Programa Integrado de Desenvolvimento Regional de Trásos-Montes

Geraldes AM, Boavida MJ (2003) Distinct age and landscape influence on two reservoirs under the same climate. Hydrobiologia 504:277-288

Geraldes AM, Boavida MJ (2004a) What factors affect the pelagic cladocerans of the Azibo meso-eutrophic reservoir? Ann Limnol-Int J Lim 40:101-111

Geraldes AM, Boavida MJ (2004b) Do littoral macrophytes influence crustacean zooplankton distribution. Limnetica 23:57-64

Geraldes AM, Boavida MJ (2005) Seasonal water level fluctuation: implications for reservoir limnology and management. Lakes Reservoirs Res Manage 10:59-69 
Hart RC (2000) Comparative long-term periodicity of Diaphanosoma excisum in adjacent warm-water impoundments, with an evaluation of contributory factors. Verh Int Verein Limnol 27:1933-1939

Hunt BP, Carbine WF (1951) Food of young pike, Esox lucius L. and associated fishes in Peterson's ditches Houghton Lake Michigan. Trans Am Fish Soc 80:6783

INAG (2006) Características das albufeiras: Dados de Base. (Cited 31 Mar 2006) http://www.snirh.inag.pt

INE (2001) Censos da População 2001. Instituto Nacional de Estatística, Lisboa

James WF, Barko JW (1991) Littoral pelagic phosphorus dynamics during night time convective circulation. Limnol Oceanogr 36:949-960

Kimmel BL, Soballe DM, Adams SM et al (1988) Interreservoir interactions: Effects of a new reservoir on organic matter production and processing in a multiple-impoundment series. Verh Int Verein Limnol 23:985-994

Lampert W, Sommer U (1997) Limnoecology - the ecology of lakes and streams. Oxford University Press, New York

Lynch M (1978) Complex interactions between natural coexploiters - Daphnia and Ceriodaphnia. Ecology 59:552-564

Murphy J, Riley JP (1962) A modified single solution method for the determination of phosphate in natural waters. Anal Chim Acta 27:31-36

Naselli-Flores L (1999) Limnological aspects of Sicilian reservoirs: a comparative ecosystemic approach. In: Tundisi JG, Straškraba M (eds) Theoretical reservoir ecology. International Institute of Ecology, Brazilian Academy of Sciences, Brazil

Naselli-Flores L, Barone R (1994) Relationship between trophic state and plankton community structure in 21 Sicilian dam reservoirs. Hydrobiologia 275/276:197205

Negro AI, De Hoyos C, Vega JC (2000) Phytoplankton structure and dynamics in Lake Sanabria and Valparaíso reservoir (NW Spain). Hydrobiologia 424:25-37
Pinel-Alloul B, Méthot G (1984) Analyse multidimensionnelle de l'evolution du zooplancton durant la mise en eau de trois reservoirs du Nord du Québec, Canada. Verh Int Verein Limnol 22:1444-1455

Robarts RD, Zohary T, Jarvis AC et al (1992) Phytoplankton and zooplankton population dynamics and production of a recently formed African reservoir. Hydrobiologia 237:47-60

Schmid-Araya JM, Zuñiga LR (1992) Zooplankton community structure in two Chilean reservoirs. Arch Hydrobiol 123:305-335

Siegfried CA, Kopache ME (1984) Zooplankton dynamics in a high mountain reservoir of southern California. Calif Fish Game 70:18-38

Sladeček V (1983) Rotifers as indicators of water quality. Hydrobiologia 100:169-201

Sokal RR, Rohlf FJ (1981) Biometry. WH Freeman \& Co, San Francisco

Ter Braak CJF (1995) Ordination. In: Jongman RHG, Ter Braak CJF, van Tongeren OFR (eds) Data analysis in community and landscape ecology. Cambridge University Press, Cambridge

Vasconcelos VM (1990a) Seasonal fluctuation in the zooplankton community of Azibo reservoir (Portugal). Hydrobiologia 196:183-191

Vasconcelos VM (1990b) First approach to the limnology of Azibo reservoir (Portugal). Publ Inst Zool "Dr A Nobre" 218:21

Watts CJ (2000a) The effect of organic matter on sedimentary phosphorus release in an Australian reservoir. Hydrobiologia 431:13-25

Watts CJ (2000b) Seasonal phosphorus release from exposed, re-inundated littoral sediments of two Australian reservoirs. Hydrobiologia 431:27-39

Wetzel RG (2001) Limnology - lake and river ecosystems. Academic Press, New York

Winfield IJ, Townsend CR (1992) The role of cyprinids in ecosystems. In: Winfield IJ (ed) Cyprinid fishes, systematics, biology and exploitation. Chapman \& Hall, London 